\title{
IDENTIFICATION OF CONTAMINANT BACTERIA IN CACHAÇA YEAST BY 16S RDNA GENE SEQUENCING
}

\author{
Osmar Vaz de Carvalho-Netto ${ }^{1}$; Daniel Dias Rosa ${ }^{2}$; Luis Eduardo Aranha Camargo ${ }^{2 *}$ \\ ${ }^{1}$ USP/ESALQ - Programa de Pós-Graduação em Microbiologia Agrícola. \\ ${ }^{2}$ USP/ESALQ - Depto. de Entomologia, Fitopatologia e Zoologia Agrícola, C.P. 09 - 13418-900 - Piracicaba, SP - \\ Brasil. \\ *Corresponding author 〈leacamar@esalq.usp.br>
}

ABSTRACT: Cachaça is a typical Brazilian liquor produced from the distillation of fermented sugarcane juice mainly by Saccharomyces cerevisiae. Most of the domestic production is artisanal, and producers usually are not concerned regarding microbiological control of the fermentation. This study aimed to characterize the contaminant bacterial community of the yeast used in the production of cachaça in an artisanal still. Four samples were collected, of which one (NA) was used for comparison purposes and was collected one year earlier. The remaining samples were collected at three different periods: at the end of the first day of fermentation (NP), after fifteen days (NS), and thirty days after the same yeast was used (NT). Five hundred and eighty-seven sequences were analyzed from the partial sequencing of the 16S rDNA gene. Sequence analyses revealed the presence of 170 operational taxonomic units (OTUs). Of these, only one was shared among three samples and seventeen were shared between two samples. The remaining 152 OTUs were identified only once in distinct samples indicating that the contaminant bacterial population is highly dynamic along the fermentation process. Statistical analyses revealed differences in bacterial composition among samples. Undescribed species in the literature on yeasts of cachaça were found, such as Weissella cibaria, Leuconostoc citreum, and some species of Lactobacillus, in addition to some unknown bacteria. The community of bacteria in the fermentation process is much more complex than it was previously considered. No previous report is known regarding the use of this technique to determine bacterial contaminants in yeast for the production of cachaça.

Key words: aguardente, alcoholic fermentation, genetic characterization, pé-de-cuba

\section{IDENTIFICAÇÃO DE BACTÉRIAS CONTAMINANTES DE FERMENTO DE CACHAÇA POR SEQÜENCIAMENTO DO GENE 16S RDNA}

RESUMO: A cachaça é uma bebida típica brasileira produzida a partir da destilação do caldo de cana-de-açúcar fermentado principalmente por Saccharomyces cerevisiae. Grande parte da produção nacional é artesanal, e não há uma preocupação por parte dos produtores quanto ao controle microbiológico da fermentação. Este trabalho objetivou caracterizar a comunidade bacteriana contaminante do fermento utilizado na produção de cachaça em um alambique artesanal. Foram coletadas quatro amostras, sendo uma (NA) utilizada como efeito comparativo e coletada um ano anterior às demais. As restantes foram coletadas em três diferentes períodos: ao final do primeiro dia de fermentação (NP), após quinze dias (NS) e trinta dias após a utilização do mesmo fermento (NT). Foram analisadas, a partir do seqüenciamento parcial do gene $16 \mathrm{~S}$ rDNA, 587 sequiências. As análises das seqüências revelaram a presença de 170 unidades taxonômicas operacionais. Destas, 152 foram identificadas uma única vez em diferentes amostras, dezessete foram comuns em pelo menos duas amostras e somente uma foi identificada em três amostras, evidenciando uma grande dinâmica populacional bacteriana durante o processo fermentativo. Análises estatísticas revelaram diferenças na composição bacteriana entre as amostras. Foram encontradas espécies ainda não descritas na literatura em fermentos para a produção de cachaça, como Weissella cibaria, Leuconostoc citreum e algumas espécies de Lactobacillus, além de bactérias não conhecidas. Os resultados revelaram que a comunidade de bactérias contaminantes do processo fermentativo é muito mais complexa do que se conhecida. Não há conhecimento de relato anterior sobre a utilização desta técnica para determinar contaminantes bacterianos em fermentos de cana-de-açúcar para produção de cachaça.

Palavras-chave: aguardente, fermentação alcoólica, caracterização genética, pé-de-cuba 


\section{INTRODUCTION}

Cachaça is the exclusive designation for the distilled beverage produced in Brazil from fermented sugarcane juice (Brasil, 1997). It is the most consumed distilled beverage in Brazil and the third most consumed worldwide (PBDAC, 2006). Brazil has about 5 thousand industrial producers and 25 thousand artisanal producers (AMPAQ, 2006). Total exports of the beverage in 2002 amounted to 14.8 million liters, representing only $1.13 \%$ of the total production (PBDAC, 2006). It is recognized that a better standardization of its composition is one of the requirements to increase the export volume of cachaça (Maia, 2002).

In artisanal production, at the end of each fermentation cycle, the sedimented yeast (pé-de-cuba) is reutilized for a new fermentation without any previous microbiological control of its content (Morais et al., 1997; Pataro et al., 1998). This practice results in the transfer of a large number of contaminant microorganisms and their metabolism products into the next fermentation (Amorim \& Oliveira, 1982; Kaji \& Canhos, 1989). Such contamination occurs both regarding wild yeasts and bacteria, including a great variation on its composition found during the entire fermentation process. The population of contaminant yeasts in cachaça production is well known and has been studied in detail (Morais et al., 1997; Pataro et al., 1998, 2000; Schwan et al., 2001). In the case of bacteria, however, only species able to be grown in laboratory have been described so far (Gallo, 1989; Yokoya, 1991; Gallo, 1992; Oliva-Neto \& Yokoya, 1994). Therefore, it is presumed that the real contaminant bacterial community of cachaça yeast is poorly understood since many bacteria are non-cultivable.

The partial sequencing of the $16 \mathrm{~S}$ ribosomal gene is quite effective and reliable in the identification of non-cultivable bacteria and characterization at the species level (Stackebrandt et al., 2002; Hongoh et al., 2003). Thus, this study aimed to characterize the contaminant bacterial community of cachaça yeast in a small still, using partial sequencing of the $16 \mathrm{~S}$ gene. This is the first such study related to cachaça production.

\section{MATERIAL AND METHODS}

\section{Collection of samples}

Sedimented yeast samples were collected in a still in the city of Monte Alegre do Sul - São Paulo State, Brazil, where the primer yeast is prepared by adding ground corn to approximately 20 liters of sugarcane juice. No control of the microbial identity of the inoculum is made, and fermentation occurs natu- rally in an open plastic jar. As fermentation increases, more sugarcane juice is added daily until the yeast is ready to support a higher volume of juice to be fermented. This occurs in about ten days, when the primer yeast is transferred to a stainless steel vat, whose volume is completed with juice. The fermentations occur at room temperature in open vats, and every 30 days the must is replaced by a new preparation. The samples were obtained in three collections distributed over 30 days, as follows: one sample was collected in the first day of fermentation (NP), another 15 days later (NS), and the third one after 30 days using the same yeast (NT). A fourth sample (NA) was collected one year earlier, in the same still, for comparison purposes. This sample was collected 12-16 days after the initial fermentation. Samples comprising of $100 \mathrm{~mL}$ of must were taken at the end of each fermentation day and were kept on a container with ice for transportation to the laboratory.

\section{DNA extraction and amplification of the 16S rDNA gene}

DNA extraction was adapted from the protocol of Hoisington et al. (1994). Samples were transferred to $1.5 \mathrm{~mL}$ microtubes and centrifuged for $5 \mathrm{~min}$ utes at maximum speed in a bench microcentrifuge. After discarding the supernatant, $600 \mu \mathrm{L}$ of CTAB solution were added $(0.7 \mathrm{M} \mathrm{NaCl}, 1 \% \mathrm{CTAB}, 50 \mathrm{mM}$ Tris $\mathrm{pH}$ 8.0, $10 \mathrm{mM}$ EDTA, 0.1\% 2-mercaptoethanol). Samples were incubated at $65^{\circ} \mathrm{C}$ for 60 minutes, and the microtubes were agitated every 10 minutes. Next, $600 \mu \mathrm{L}$ of a chloroform:isoamyl alcohol solution (CIA) (24:1) were added, followed by a new centrifugation for 10 minutes at $13,000 \mathrm{rpm}$. The supernatant was transferred to a new microtube and then added of 600 $\mu \mathrm{L}$ CIA, and centrifuged one more time. The removed supernatant was added of $500 \mu \mathrm{L}$ ethanol $100 \%$, and the microtubes were maintained for one hour at $-20^{\circ} \mathrm{C}$ to precipitate the DNA. After that period, the microtubes were centrifuged at $13,000 \mathrm{rpm}$ for 12 minutes, during which DNA precipitation occurred. The precipitate was rinsed with ethanol $90 \%$ for 1 minute and then with absolute ethanol for another minute. Next, after the DNA was dried and resuspended in $50 \mu \mathrm{L}$ sterile water, digestion was conducted at room temperature for 12 hours with $2 \mu \mathrm{L}$ of the RNAse enzyme $\left(1 \mathrm{mg} \mathrm{mL}^{-1}\right)$ per sample.

The partial amplification of the 16S rDNA was made by conducting a PCR in a final volume reaction of $25 \mu \mathrm{L}$ using $20 \mathrm{ng}$ of DNA; $1 \mu \mathrm{L}$ of universal primers 968 forward (5' AAC GCG AAG AAC CTT AC $\left.3^{\prime}\right)$ and the same quantity of 1401 reverse (5' CGG TGT GTA CAA GAC CC 3') (Nubel et al., 1996), at an initial concentration of $5 \mathrm{pmol} ; 2,5 \mu \mathrm{L}$ of $10 \mathrm{X}$ 
ThermalAce buffer (Invitrogen Life Technologies, Carlsbad, CA); $1 \mathrm{U}$ of ThermalAce DNA polymerase (Invitrogen Life Technologies, Carlsbad, CA); 0,2 $\mu \mathrm{L}$ of dNTP $(10 \mathrm{mM})$. The amplification program consisted of 3 minutes denaturation at $94^{\circ} \mathrm{C}$, followed by 25 cycles of 30 seconds at $94^{\circ} \mathrm{C}, 30$ seconds at $56^{\circ} \mathrm{C}$, and 1 minute at $72^{\circ} \mathrm{C}$. A final 5-minute extension was performed at $72^{\circ} \mathrm{C}$. PCR products were purified using the GFX purification kit (Amersham Biosciences, Piscataway, NJ) according to the manufacturer's instructions.

\section{Cloning and sequencing of the $16 \mathrm{~S}$ rDNA gene}

In order to sequence the PCR products, the fragments were attached to the pGEM T-Easy Vector Systems, according to the manufacturer's instructions (Promega Corporation, Madison, WI). Recombinant plasmids were transformed in Escherichia coli DH10 $\alpha$ (Invitrogen Life Technologies, Carlsbad, CA) by electroporation. Plasmid extraction was performed by the alkaline lysis method (Sambrook et al., 1989).

The sequence reaction was performed using approximately $400 \mathrm{ng}$ DNA, $2 \mu \mathrm{L}$ of Big Dye Terminator kit (Applied Biosystem, Foster City, CA), $1 \mu \mathrm{L}$ of primer M13 forward (5'TGT AAA ACG ACG GCC AGT 3') (3.2 pmol) and $2 \mu \mathrm{L}$ of Save Money buffer (200 mM Tris- $\mathrm{HCl} \mathrm{pH} 9,5 \mathrm{mM} \mathrm{MgCl}$ ). Amplification conditions consisted of 25 cycles of 10 seconds at $96^{\circ} \mathrm{C}, 5$ seconds at $50^{\circ} \mathrm{C}$, and 4 minutes at $60^{\circ} \mathrm{C}$. Sequencing of plasmid inserts was performed in an $\mathrm{ABI}$ 377 sequencing machine (Perkin-Elmer/Applied Biosystems, Foster City, CA).

\section{Data analysis}

Sequence quality was analyzed using the Phred/Phrap/Consed software (Ewing et al., 1998; Gordon et al., 2001). Only sequences of 300 bases in length or longer and with at least 200 bases with a Phred quality equal to or higher than 20 were used. Primer sequences were identified and trimmed using the BioEdit software (http://www.mbio.ncsu.edu/ BioEdit/page2.html).

Sequence identity was preliminary defined using the BlastN software in order to exclude non-bacterial sequences, such as chloroplast. Sequences with less than $95 \%$ similarity to any previously identified sequence in GenBank were analysed online by the Ribosomal Database Project (RDP) CHIMERA-CHECK software (Cole et al., 2003). Sequences that appeared to be chimeric were discarded. Operational taxonomic units (OTUs) were determined firstly by aligning the sequences using the CLUSTAL $\mathrm{X}$, version 1.81 software (Thompson et al., 1997), with a "gap-opening penalty" parameter of 10.0 and a "gap-extension penalty" of 0.1 . The evolutionary distance matrix was cal- culated using the DNADIST software of the PHYLIP software, version 3.63 (Felsenstein, 1995) via the Jukes-Cantor model using a 3\% difference $(\mathrm{D}=0.03)$ for discriminating OTU via the DOTUR software (Schloss \& Handelsman, 2005).

The taxonomic identification of the OTUs was made via the Bayesian Sequence Classifier software of RDP II (Cole et al., 2003), using a confidence limit of $80 \%$. Whenever possible, the OTUs were putatively identified at the species level by similarity comparisons regarding sequences of other organisms deposited in GenBank (http://www.ncbi.nlm.nih.gov) using the BlastN software (Altschul, et al., 1990). According to López et al. (2006), the identification of bacteria at the species level can be inferred if the fragment sequence shows similarity values above $97 \%$.

Overall and sample estimates of species richness were calculated by the SPADE software (Chao $\&$ Shen, 2003) using the nonparametric estimators ACE and Chao 1. Shannon diversity indices, Simpson's reciprocal (for identification of dominant OTUs), and the sampling coverage of the sequenced clones were also calculated using the SPADE software.

Significant differences in the bacterial composition among samples were detected by comparison to their homologous curves with the S-LIBSHUFF software (Schloss et al., 2004).

\section{RESULTS}

Seven hundred and seven sequences with an average of 430 bases each were analyzed using the BlastN software. Of these, 560 were phylogenetically classified next to cultivated bacteria and 27 as unkown bacteria. The DNA sequences were deposited in GenBank and given the accession numbers EU186842 through EU187426. One hundred and twenty sequences were identified as sugar cane chloroplast and discarded.

The 587 sequences were classified into 170 OTUs via the DOTUR software. Only one of these, identified as Lactobacillus hilgardii, was shared among three samples (NA, NS, and NT) and seventeen were shared between two samples. The remaining 152 OTUs were considered unique, i.e., they were not detected in more than one sample. The NS and NT samples shared the highest number of OTUs (Table 1).

Seven OTUs could not be classified at the phylum level according to the RDP Bayesian Sequence Classifier and BlastN softwares. The others were classified into four phyla: Firmicutes, Actinobacteria, Proteobacteria and Chlamydiae (Table 2). Two bacterial classes predominated: Bacilli, with 435 sequences distributed in 123 OTUs; and Actinobacteria, with 119 sequences in 33 OTUs. 
Estimates of species richness revealed the following values: 177 OTUs for the NA sample, 76 for NP, 173 for NS, and 129 for NT, with coverage percentages of $59 \%, 89 \%, 76 \%$, and $85 \%$, respectively (Table 3 ). Richness estimates using the nonparametric methods ACE and Chao 1 indicated no differences $(95 \%$ probability confidence interval) in number of species among samples. Shannon indexes corroborated these results althougth the NA sample showed a higher diversity index than the other samples, but not different from the NS sample.
Table 1 - Number of common OTUs between samples.

\begin{tabular}{lccc}
\hline \multirow{2}{*}{ Sample } & \multicolumn{3}{c}{ Samples } \\
\cline { 2 - 4 } & NP & NS & NT \\
\hline NA & 1 & 1 & 3 \\
NP & - & 3 & 2 \\
NS & - & - & 9 \\
\hline
\end{tabular}

NA: sample for comparison purposes, collected one year before the others; NP: collection at the end of the first day of fermentation; NS: collection after fifteen days using the same yeast; NT: collection at the end of thirty days using the same yeast.

Table 2 - Number and identity of bacterial contaminant OTUs of yeast for the production of cachaça, identified via the RDP and GenBank databases.

\begin{tabular}{|c|c|c|c|c|c|c|c|}
\hline Taxonomy* & & & & & & $\begin{array}{l}\text { N. of } \\
\text { OTUs }\end{array}$ & $\%$ of seq \\
\hline Phylum & Class & Order & Family & Genus & Species & & \\
\hline Chlamydiae & Chlamydiae & Chlamydiales & Parachlamydiaceae & Parachlamydia & Unidentified & 2 & 0.34 \\
\hline \multirow[t]{15}{*}{ Firmicutes } & Bacilli & Lactobacillales & Lactobacillaceae & Lactobacillus & brevis & 11 & 8.07 \\
\hline & & & & & hilgardii & 11 & 19.89 \\
\hline & & & & & casei & 5 & 5.64 \\
\hline & & & & & plantarum & 5 & 10.61 \\
\hline & & & & & acetotolerans & 1 & 0.34 \\
\hline & & & & & spicheri & 1 & 1.02 \\
\hline & & & & & Unidentified & 65 & 21.29 \\
\hline & & & & Unidentified & & 2 & 0.34 \\
\hline & & & Leuconostocaceae & Leuconostoc & mesenteroides & 6 & 3.75 \\
\hline & & & & & citreum & 4 & 3.41 \\
\hline & & & & & Unidentified & 4 & 1.02 \\
\hline & & & & Weissella & cibaria & 1 & 0.34 \\
\hline & & & Streptococcaceae & Lactococcus & lactis & 1 & 0.17 \\
\hline & & & Unidentified & & & 2 & 0.68 \\
\hline & & Unidentified & & & & 2 & 0.51 \\
\hline \multirow[t]{10}{*}{ Actinobacteria } & Actinobacteria & Actinomycetales & Dermabacteraceae & Brachybacterium & Unidentified & 1 & 0.17 \\
\hline & & & Microbacteriaceae & Curtobacterium & flaccumfaciens & 5 & 9.71 \\
\hline & & & & & Unidentified & 9 & 4.73 \\
\hline & & & & Leifsonia & $x y l i$ & 6 & 2.19 \\
\hline & & & & & Unidentified & 6 & 1.02 \\
\hline & & & & Microbacterium & Unidentified & 1 & 1.19 \\
\hline & & & Propionibacteriaceae & Propionibacterium & acidipropionici & 1 & 0.34 \\
\hline & & & Streptomycetaceae & Unidentified & & 1 & 0.17 \\
\hline & & & Unidentified & & & 2 & 0.34 \\
\hline & & Bifidobacteriales & Bifidobacteriaceae & Bifidobacterium & psychroaerophilum & 1 & 0.17 \\
\hline \multirow[t]{7}{*}{ Proteobacteria } & Alphaproteobacteria & Rhodobacterales & Rhodobacteraceae & Amaricoccus & tamworthensis & 1 & 0.17 \\
\hline & & Unidentified & & & & 1 & 0.17 \\
\hline & Betaproteobacteria & Burkholderiales & Burkholderiaceae & Burkholderia & Unidentified & 1 & 0.17 \\
\hline & & & & Cupriavidus & Unidentified & 1 & 0.17 \\
\hline & Gammaproteobacteria & Enterobacteriales & Enterobacteriaceae & Buttiauxella & izardii & 1 & 0.34 \\
\hline & & & & Kluyvera & Unidentified & 1 & 0.17 \\
\hline & & Xanthomonadales & Xanthomonadaceae & Xanthomonas & albilineans & 1 & 0.17 \\
\hline Unidentified & & & & & & 7 & 1.19 \\
\hline Total & & & & & & 170 & 100 \\
\hline
\end{tabular}

*Identity of OTUs obtained by comparison with ribosomal sequences from other organisms deposited in the RDP Classifier and GenBank databases. 
Table 3 - Richness estimates of OTUs identified in the four samples and corresponding diversity indexes and coverage percentages.

\begin{tabular}{|c|c|c|c|c|c|c|c|}
\hline \multirow[b]{2}{*}{ Sample } & \multirow[b]{2}{*}{$\mathrm{NC}$} & \multirow[b]{2}{*}{$\mathrm{NU}$} & \multicolumn{2}{|c|}{ Richness estimate of OTUs } & \multicolumn{3}{|c|}{ Diversity indices } \\
\hline & & & $\mathrm{ACE}$ & Chao 1 & Shannon & $1 / \mathrm{D}$ & ECA \\
\hline NA & 81 & 43 & $177(98 ; 368)$ & $179(88 ; 456)$ & $3,340(3,122 ; 3,558)$ & $17.49(30.21 ; 12.31)$ & 0.593 \\
\hline NP & 177 & 38 & $76(54 ; 132)$ & $67(47 ; 125)$ & $2,658(2,449 ; 2,867)$ & $6.82(13.34 ; 4.58)$ & 0.887 \\
\hline NS & 159 & 57 & $173(109 ; 313)$ & $129(87 ; 230)$ & $3,055(2,804 ; 3,305)$ & $7.63(16.42 ; 4.97)$ & 0.761 \\
\hline NT & 170 & 38 & $129(72 ; 277)$ & $194(77 ; 672)$ & $2,723(2,534 ; 2,913)$ & $9.00(16.24 ; 6.22)$ & 0.853 \\
\hline All & 587 & 170 & $519(391 ; 720)$ & $453(333 ; 660)$ & $4,107(3,984 ; 4,230)$ & $25.95(37.33 ; 19.88)$ & 0.806 \\
\hline
\end{tabular}

NA: sample for comparison purposes, collected one year before the others; NP: collection at the end of the first day of fermentation; NS: collection after fifteen days using the same yeast; NT: collection at the end of thirty days using the same yeast. NC: number of clones per sample; NU: number of OTUs identified by the DOTUR software. ECA: coverage estimate in the sample. Shannon: maximum similarity estimator. 1/D: Simpson's maximum similarity estimator, reciprocal of the index. Values between parentheses represent the interval at $95 \%$ confidence.

Simpson's reciprocal values were not different among samples with regard to the presence of dominant OTUs in the bacterial communities. All samples showed quite diversified communities and few OTUs represented large quantities of sequences.

Statistical analyses using the S-LIBSHUFF software revealed that all samples differed significantly from one another $(p<0.05)$ as compared to their homologous curves, thus indicating that the bacterial communities are qualitatively different from one another.

\section{DISCUSSION}

Species richness estimates among samples did not differ in numbers of species. All had high estimates, averaging 132 species, according to the ACE estimator. However, the results of analyses by the SLIBSHUFF software indicated that the samples differed in their bacterial composition. Such diversity indicates that the contaminant bacterial community is dynamic, with variations occurring along time in the same batch. These variations reflect the lack of microbiological standardization of the process and are responsible for differences in quality of the final product (Amorim \& Oliveira, 1982; Kaji \& Canhos, 1989; Gallo, 1989, 1992; Schwan et al., 2001). Based on these results, the contaminant bacterial community is much larger, more dynamic, and more complex than reported in the literature. However, despite the diversity, a small number of unknown bacteria were found in the samples: approximately $5 \%$ of the total. This indicates that vats of fermented sugarcane juice do not represent a very complex environment compared to environmental samples, like soil, in which the percentage of unknown bacteria could be almost 99\% (Staley \& Konopka, 1985).

Among the components of this diversity, the identification of certain OTUs common to all samples also indicates that some bacterial species occur frequently, such as Lactobacillus brevis and L. hilgardii. This suggests that, although variable, some OTUs are frequent contaminants of the cachaça yeast. As reported before, (Althertum et al., 1984; Gallo, 1989; Yokoya, 1991; Gallo, 1992; Oliva-Neto \& Yokoya, 1994), the genus Lactobacillus was predominant, accounting for approximately $66 \%$ of the sequences, of which $32 \%$ could not be identified at the species level. Thus, the potential presence of new Lactobacillus species in the sample can be inferred, since their identification at the species level in the databases could not be done. Two species of this genus (Lactobacillus acetotolerans and $L$. hilgardii) were detected that have not yet been described in sugarcane yeasts. In addition to being common in sugar-rich, fermentation-favorable environments, the genus Lactobacillus characteristically can become adapted to the medium, and some species are more resistant to the alcohol that is present toward the end of fermentation (Gold et al., 1992), which explains their higher quantities and species diversity identified in the samples as compared to other genera.

Among the bacteria, the genera Leuconostoc and Lactobacillus were important, as they were found in all samples in large numbers with a great diversity of species. Species of Leuconostoc mesenteroides, Lactobacillus plantarum, and L. brevis were described in the literature as contaminants of cachaça fermentation vats (Oliva-Neto \& Yokoya, 1994; Schwan et al., 2001).

However, the great majority of bacteria present in the samples had not been described in this environment, but associated with the fermentation of other fermented alcoholic beverages and foods, such as $L$. acetotolerans, identified in silages (Cai et al., 1999), cheese (Baruzzi et al., 2000) and in pulque, a Mexican alcoholic beverage (Escalante et al., 2004); L. hilgardii, in pulque (Escalante et al., 2004), cheese (Baruzzi et al., 2000), and wine (Rodas et al., 2005); 
Leuconostoc citreum, identified in kimchi, a food prepared from fermented cabbage (Choi et al., 2003), shochu, a Japanese distilled beverage (Endo \& Okada, 2005) and in fermented milks in South Africa (Beukes et al., 2001); and Weissella cibaria, isolated from sugarcane and fermented foods typical of Malaysia (Bjorkroth et al., 2002). The bacterial communities present in these fermentative processes are very similar, regardless of the raw material used, and are characterized by the presence of lactic acid species, especially in the genera Lactobacillus, Leuconostoc, Weissella and Lactococcus. Many species in these genera characteristically are resistant to low $\mathrm{pH}$ values and to high alcohol concentrations (Huhtamella et al., 2007), which explains their presence and wide distribution in different fermentative processes, both alcoholic and lactic.

Skinner \& Leathers (2004), in a similar study on the identification of contaminant bacteria in fermented corn vats for alcohol production, found a bacterial population similar to our study, which shared nine species and six common genera and a community that, again, predominantly consisted of Lactobacillus. Similar results were also observed in other alcoholic fermentation samples, such as pulque (Escalante et al., 2004), shochu (Endo \& Okada, 2005), and whisky (Beek \& Priest, 2003). These results reveal that there is a pattern of species that participate in alcoholic fermentation in several processes.

The identity analyses of sequences with the BlastN software revealed that lactic acid bacteria were present in abundant quantities and diversity. These bacteria ferment glucose and produce lactic acid as their main metabolic product (Liu, 2003), thus reducing alcoholic fermentation yield. The microbial community present during fermentation is also responsible for the production of secondary compounds, such as alcohols, aldehydes, organic acids, and esters. These compounds, at balanced quantities, are responsible for the development of flavor and aroma (bouquet) (Packowski, 1978). Lactic acid heterofermentative bacteria, such as Lactobacillus acetotolerans, L. hilgardii, L. brevis and Leuconostoc mesenteroides (Stiles \& Holzapfel, 1997) may produce $\mathrm{CO}_{2}$, ethanol, mannitol, acetic acid, and small quantities of acetaldehydes, in addition to lactic acid, which, much probably, contribute toward the final chemical composition of the beverage (Escalante et al., 2004).

Species of Lactobacillus, Leuconostoc, and Propionibacterium contribute to the formation of the cachaça bouquet; however, in large amounts they are considered detrimental (Schwan et al., 2001). In a study about the influence of lactic acid bacteria on fermentation for the production of whisky, Geddes \&
Riffkin (1989) observed that the presence of Lactobacillus during fermentation is also essential for the development of a bouquet in this beverage. Qualitatively, the aroma components of cachaça are the same found in other fermented and distilled beverages. In many respects, fermentation is more determinative than the raw material in the formation of a liquor's secondary components (Maia, 1994). In such cases, the presence of bacteria during fermentation in balanced quantities could not be considered a contaminant element, but rather an essential component of the final quality of the beverage. However, not much information is available with regard to the composition and concentration of these microorganisms for cachaça production. Therefore, a greater diversity of studies in this area is suggested for a better understanding of the relation between microorganisms involved in the fermentation process and the final chemical quality of the beverage produced.

The use of this molecular technique to identify bacteria present in cachaça yeast revealed a community composition much more diverse than previously described, thus broadening our knowledge about microorganisms that take part in fermentation. This study indicates that further studies targeted at understanding the contribution of these microorganisms to the fermentation process of cachaça must be considered. In addition, knowledge about the role played by these microorganisms will help to preserve the artisanal and valued method of preparation of this product.

\section{ACKNOWLEDGEMENTS}

To CNPq - Conselho Nacional de Desenvolvimento Científico e Tecnológico, Brazil, to Msc. Gisele Lopes Nunes for helping with the molecular analysis.

\section{REFERENCES}

ALTHERTUM, F.; CRUZ, M.R.M.; VAIRO, M.L.R.; GAMBASSI, D.M. Efeito dos microrganismos contaminantes da fermentação alcoólica nas microdestilarias. STAB. Açúcar, Álcool e Subprodutos, v.3, p.42-49, 1984.

ALTSCHUL, S.F; GISH, W.; MILlER, W.; MYERS, E.W.; LIPMAN, D.J. Basic local alignment search tool. Journal of Molecular Biology, v.215, p.403-410, 1990.

AMORIM, H.V.; OLIVEIRA, A.J. Infecção na fermentação: como evitá-la. Álcool e Açúcar, São Paulo, v.2, p.12-18, 1982.

ASSOCIAÇÃO MINEIRA DOS PRODUTORES DE CACHAÇA DE QUALIDADE - AMPAQ. Available at: http:// www.ampaq.com.br. Accessed 16 Nov. 2006.

BRASIL. MINISTÉRIO DA AGRICULTURA, PECUÁRIA E DO ABASTECIMENTO. Decreto ${ }^{\circ} 2.314$ de 04 de setembro de 1997. Regulamenta a Lei $\mathrm{n}^{\circ} 8.918$, de 14 de julho de 1994 , que dispõe sobre a padronização, a classificação, o registro, a inspeção, a produção e a fiscalização de bebidas. Diário Oficial da União, n.171, seção I, p.19556, 1997. 
BARUZZI, F.; MOREA, M.; MATARANTE, A.; COCCONCELLI, P.S. Changes in the Lactobacillus community during ricotta forte cheese natural fermentation. Journal of Applied Microbiology, v.89, p.807-814, 2000.

BEEK, S. van; PRIEST, F.G. Bacterial diversity in Scotch whisky fermentations as revealed by denaturing gradient gel electrophoresis. Journal of American Society of Brewing Chemists, v.61, p.10-14, 2003.

BEUKES, E.M.; BESTER, B.H.; MOSTERT, J.F. The microbiology of South African traditional fermented milks. International Journal of Food Microbiology, v.63, p.189-197, 2001.

BJORKROTH, K.J.; SCHILLINGER, U.; GEISEN, R.; WEISS, N.; HOSTE, B.; HOLZAPFEL, W.H.; KORKEALA, H.J.; VANDAMME, P. Taxonomic study of Weissella confusa and description of Weissella cibaria sp. nov., detected in food and clinical samples. International Journal of Systematic Evolutionary Microbiology, v.52, p.141-148, 2002.

CAI, Y.; KUMAI, S.; OGAWA, M.; BENNO, Y.; NAKASE, T. Characterization and identification of Pediococcus species isolated from forage crops and their application for silage preparation. Applied and Environmental Microbiology, v.65, p.2901-2906, 1999.

CHAO, A.; SHEN, T.J. Program SPADE: Species Prediction and Diversity Estimator. 2003. Available at: http:// chao.stat.nthu.edu.tw/softwareCE.html. Accessed 2 Apr. 2007.

CHOI, I.K.; JUNG, S.H.; KIM, B.J.; PARK, S.Y.; KIM, J.; HAN, H.U. Novel Leuconostoc citreum starter culture system for the fermentation of kimchi, a fermented cabbage product. Antonie van Leeuwenhoek, v.84, p.247-253, 2003.

COLE, J.R.; CHAI, B.; MARSH, T.L.; FARRIS, R.J., WANG, Q.; KULAM, S.A.; CHANDRA, S.; McGARRELL, D.M.; SCHMIDT, T.M.; GARRITY, G.M.; TIEDJE, J.M. The ribosomal database project (RDP II): previewing a new autoaligner that allows regular updates and the new prokaryotic taxonomic. Nucleic Acids Research, v.31, p.442-443, 2003.

ENDO, A.; OKADA, S. Monitoring the lactic acid bacteria diversity Shochu fermentation by PCR-denaturing gradient gel electrophoresis. Journal of Bioscience and Bioengineering, v.99, p.216-221, 2005.

ESCALANTE, A.; RODRÍGUEZ, M.E.; MARTÍNEZ, A.; LÓPEZMUNGUÍA, A.; BOLÍVAR, F.; GOSSET, G. Characterization of bacterial diversity in Pulque, a traditional Mexican alcoholic fermented beverage, as determined by $16 \mathrm{~S}$ rDNA analysis. FEMS Microbiology Letters, v.235, p.273-279, 2004.

EWING, B.; HILLIER, L.; WENDL, M.; GREEN, P. Basecalling of automated sequencer traces using Phred I and Phred II. Accuracy assessment and error probabilities. Genome Research, v.8, p.175-194, 1998.

FELSENSTEIN, J. PHYLIP: Phylogeny Inference Package; version 3.61. Seattle: University of Washington/Department of Genetics, 1995. Available at: http://evolution.genetics.washington.edu/ phylip/phylip.html.

GALLO, C.R. Determinação da microbiota bacteriana de mosto e de dornas de fermentação alcoólica. Campinas: Universidade Estadual de Campinas, 1989. 388p. Tese (Doutorado).

GALLO, C.R. Identificação de bactérias contaminantes da fermentação alcoólica. STAB. Açúcar, Álcool e Subprodutos, v.2, p.30-34, 1992.

GEDDES, P.A.; RIFFKIN, H.L. Influence of lactic acid bacteria on aldehyde, ester and higher alcohol formation during Scoth whisky fermentation. In: PIGGOT, J.R.; PATERSON, A. (Ed.) Distelled beverage flavours. Chichester: Ellis Horwood, 1989. chap.17, p.193-199.

GOLD, R.S.; MEAGHER, M.M.; HUTKINS, R.; CONWAY, T. Ethanol tolerance and carbohydrate metabolism in Lactobacilli. Journal of Industrial Microbiology and Biotechnology, v. 10, p. $45-54,1992$.

GORDON, D.; DESMARAIS, C.; GREEN, P. Automated finishing with autofinish. Genome Research, v.11, p.614-625, 2001.
HOISINGTON, D.; KAIRHALLAH, M.; GONZALEZ-DE-LEON, D. Laboratory protocols. 2 ed. México, DF: CIMMYT, 1994. $51 \mathrm{p}$

HONGOH, Y.; YUZAWA, H.; OHKUMA, M.; KUDO, T. Evaluation of primers and PCR conditions for the analysis of 16S rRNA genes from a natural environment. FEMS Microbiology Letters, v.221, p.299-304. 2003.

HUHTAMELLA, S.; LEINONEN, M.; NIEMINEN, T.; FAHNERT, B.; MYLLYKOSKI, L.; BREITENSTEIN, A.; NEUBAUER P. RNA-based sandwich hybridisation method for detection of lactic acid bacteria in brewery samples. Journal of Microbiological Methods, v.68, p.543-553, 2007.

KAJI, D.A.; CANHOS, V.P. Contaminantes do processo de produção de açúcar e álcool. In: EGUCHI, S.Y.; YOKOYA, F.; CANhos, V.P.; GAllo, C.R. Pontos críticos microbiológicos em usinas de açúcar e álcool. Campinas: Fundação Tropical de Pesquisas e Tecnologia "André Tosello", 1989. cap.1, p.1-9.

LIU, S.Q. Practical implications of lactate and pyruvate metabolism by lactic acid bacteria in food and beverage fermentations. International Journal of Food Microbiology, v.83, p.115$131,2003$.

LÓPEZ, M.A.; SERNA, F.J.Z.D.; JAN-ROBLERO, J.; ROMERO, J.M.; HERNÁNDEZ-RODRÍGUEZ, C. Phylogenetic analysis of a biofilm bacterial population in a water pipeline in the Gulf of Mexico. FEMS Microbiology Ecology, v.58, p.145-154, 2006.

MAIA, A.B. Componentes secundários da aguardente. STAB. Açúcar, Álcool e Subprodutos, v.12, p.29-34, 1994.

MAIA, F.S. Alternativas para exportação de cachaça: um exemplo da Alemanha. Lavras: Universidade Federal de Lavras, 2002. 28p. (Boletim Técnico,57).

MORAIS, P.B.; ROSA, C.A.; LINARDI, V.R.; PATARO, C.; MAIA, A.B.R.A. Characterization and succession of yeast populations associated with spontaneous fermentations during the production of the Brazilian sugar-cane aguardente. World Journal of Microbiology and Biotechnology, v.13, p.241243, 1997.

NUBEL, U. ENGELEN, B.; FELSKE, A.; SNAIDR, J.; WIESHUBER, A.; AMANN, R.I.; LUDWIG, W.; BACKHAUS, $\mathrm{H}$. Sequence heterogeneities of genes encoding $16 \mathrm{~S}$ rRNAs in Paenibacillus polymyxa detected by temperature gradient gel electrophoresis. Journal of Bacteriology, v.178, p.56365643,1996

OLIVA-NETO, P.; YOKOYA, F. Evaluation of bacterial contamination in a fed-batch alcoholic fermentation process. World Journal of Microbiology and Biotechnology, v.10, p.697-699, 1994

PACKOWSKI, G.W. Beverage spirits, distilled. In: KIRK, R.E.; OTHMER, D.F. (Ed.) Encyclopedia of chemical technology. 3 ed. New York: John Wiley, 1978. v.3, p.830-863.

PATARO, C.; SANTOS, A.; CORREA, S.R.; MORAIS, P.B.; LINARDI, V.R.; ROSA, C.A. Physiological characterization of yeasts isolated from artisanal fermentation in an aguardente distillery. Revista de Microbiologia, v.29, p.69-73, 1998.

PATARO, C.; GUERRA, J.B.; PETRILLO-PEIXOTO, M.L.; MENDONÇA-HAGLER, L.C.; LINARDI, V.R.; ROSA, C.A. Yeast communities and genetic polymorphism of Saccharomyces cerevisiae strains associated with artisanal fermentation in Brazil. Journal of Applied Microbiology, v.89, p.24, 2000

PROGRAMA BRASILEIRO DE DESENVOLVIMENTO DA CACHAÇA - PBDAC. Available at: http://www.pbdac.com.br. Accessed 18 Apr. 2006.

RODAS, A.M; FERRER, S; PARDO, I. Polyphasic study of wine Lactobacillus strains: taxonomic implications. International Journal of Systematic and Evolutionary Microbiology, v.55, p.197-207, 2005.

SAMBROOK, J.; FRITSCH, E.F.; MANIATIS, T. Molecular cloning: a laboratory manual. 2 ed. New York: Cold Spring Harbor Laboratory Press, 1989. v.3, 1659p. 
SCHLOSS, P.; LARGET, B.R.; HANDELSMAN, J. Integration of microbial ecology and statistics: a test to compare gene libraries. Applied and Environmental Microbiology, v.70, p.54855492, 2004.

SCHLOSS, P.; HANDELSMAN, J. Introducing DOTUR, a computer program for defining operational taxonomic units and estimating epecies richness. Applied and Environmental Microbiology, v.71, p.1501-1506, 2005.

SCHWAN, R.F.; MENDONÇA, A.T.; SILVA-JÚNIOR., J.J.; RODRIGUES, V.; WHEALS, A.E. Microbiology and physiology of cachaça (aguardente) fermentations. Antonie van Leeuwenhoek, v.79, p.89-96, 2001.

SKINNER, K.A.; LEATHERS, T.D. Bacterial contaminants of fuel ethanol production. Journal of Industrial Microbiology and Biotechnology, v.31, p.401-408, 2004.

STACKEBRANDT, E.; FREDERIKSEN, W.; GARRITY, G.M.; GRIMONT, P.A.D.; KAMPFER, P.; MAIDEN, M.C.J.; NESME, X.; ROSSELLÓ-MORA, R.; SWINGS, J.; TRUPER, H.G.; VAUTERIN, L.; WARD, A.C.; WHITMAN, W.B. Report of the ad hoc committee for the re-evaluation of the species definition in bacteriology. International Journal of Systematic and Evolutionary Microbiology, v.52, p.10431047, 2002.
STALEY, J.T.; KONOPKA, A. Measurement of in situ activities of non-photosynthetic microorganisms in aquatic and terrestrial habitats. Annual Review of Microbiology, v.39, p.321-346, 1985.

STILES, M.E.; HOLZAPFEL, W.H. Lactic acid bacteria of foods and their current taxonomy. International Journal of Food Microbiology, v.36, p.1-29, 1997.

THOMPSON, J.D.; GIBSON, T.J.; PLEWNIAK, F.; JEANMOUGIN, F.; HIGGINS, D.G. The CLUSTAL_X windows interface: flexible strategies for multiple sequence alignment aided by quality analysis tools. Nucleic Acids Research, v.25, p.4876-4882, 1997.

YOKOYA, F. Problemas com contaminantes na fermentação alcoólica. STAB. Açúcar, Álcool e Subprodutos, v.9, p.38-39, 1991.

Received June 15, 2007

Accepted February 08, 2008 